\title{
The section Atlanticae of the genus Luzula (Juncaceae)
}

\author{
A. $\mathrm{ROMO}^{1} \&$ A. BORATYŃSKI ${ }^{2}$ \\ ${ }^{\mathbf{1}}$ Botanical Institute of Barcelona (IBB-CSIC-ICUB), Psg. del Migdia s/n., Parc de Montjuïc, E-08038 Barcelona, Spain \\ ${ }^{2}$ Institute of Dendrology, Polish Academy of Sciences, Parkowa 5, 62-035 Kórnik, Poland \\ Author for correspondence: A. M. Romo (a.romo@ibb.csic.es) \\ Editor: M. Galbany-Casals
}

Received 1 October 2010; Accepted 5 October 2011

\begin{abstract}
The section Atlanticae of the genus Luzula (Juncaceae).- Luzula atlantica Braun-Blanq. and Luzula tibestica (Quézel) Zarhan ex Romo \& Boratyński are the only representatives of the section Atlanticae Kirschner of the genus Luzula. Luzula atlantica is an endemic plant from the High Atlas Mountains and Luzula tibestica is endemic to the Tibesti massif. Both taxa are studied from a nomenclatural, morphological, chorological and biogeographical point of view. These taxa, owing to their low dispersion capacity, have probably diversified in situ.
\end{abstract}

Key words: Atlas Mountains; Juncaceae; Luzula; oromediterranean taxon; Tchad; Tibesti massif.

\begin{abstract}
Resumen
La sección Atlanticae del género Luzula (Juncaceae).- Luzula atlantica Braun-Blanq. y Luzula tibestica (Quézel) Zarhan ex Romo \& Boratyński son los únicos representantes de la sección Atlanticae Kirschner del género Luzula. Luzula atlantica es un endemismo del Alto Atlas y Luzula tibestica es una planta endémica del macizo de Tibesti. Ambos taxones son estudiados desde el punto de vista morfológico, nomenclatural, corológico y biogeográfico. Estos taxones, por su baja tasa de dispersión, se han diversificado probablemente in situ.
\end{abstract}

Palabras clave: Chad; Juncaceae; Luzula; macizo de Tibesti; montañas del Atlas; taxon oromediterráneo.

\section{INTRODUCTION}

The presence of closely-related vascular plant taxa in isolated mountainous zones has drawn the attention of the biogeographers (Quézel, 1978, 1981, 2002; Quézel \& Médail, 2003) and has become a challenge when facing theories of long distance dispersion and/or vicariance. In the case of Luzula DC., for Mediterranean Maghreb region, it is represented by five taxa, each one inhabiting distinct mountainous zones (Maire, 1957). Only one is found in the SaharoArabian region, and five are present in Sub-Saharan Africa (Klopper et al., 2006).
This type of present distribution causes us to reconsider the role of the Saharo-Arabian region, and its possible function as a great barrier for long-distance dispersal on the one hand, and on the other, the protagonism of the great massifs that dot the SaharoArabian region from the highlands of Ethiopia, the Nuba Mountains, Jbel Marra, Tibesti Massif, Ain and Hoggar Massif across to the Atlas range, in vicariance processes. To what point have these massifs served as migratory routes in both directions in past ages and other climatic scenarios for the ancestors of some representatives of the present flora? Do taxa exist at present in these massifs and ranges which demonstrate 
the hypothesis of vicariance as opposed to long distance dispersal? What can the study of the Atlanticae section of the genus Luzula contribute to this end?

The section Atlanticae of the genus Luzula was described by Kirschner \& Kaplan $(2001 a, b)$, and until now only included one taxon: Luzula atlantica Braun-Blanq. This section exhibits a number of characters very unusual in the genus Luzula, such as: globose, smooth and shining seeds; reduced style; and membranous tepals with a brown, mucronate midrib. It is one of the seven sections recognized in this genus. Luzula atlantica is morphologically intermediate between species of sections Anthelaea and Diprophyllatae (Kirschner et al., 2002). Nonetheless this reality does not correspond with molecular data (Drábková \& Vlcek, 2010).

\section{MATERIAL AND METHODS}

The herbarium material of MPU (Montpellier), P (Paris), and AIX (Aix en Provence) has been revised, and the literature references of these taxa under study have been consulted. The type specimens of Luzula atlantica and L. atlantica subsp. tibestica Quézel have been examined. Also the morphology, chorology and distribution of the taxa within the section have been studied. The paleo-biogeografical and paleo-ecological data have been analysed in order to evaluate the adaptive radiation of these taxa.

\section{RESULTS AND DISCUSSION}

\section{Taxonomy}

A revision of the herbarium material and the literature has led us to recognize a second taxon: Luzula tibestica (Quézel) Zahran ex Romo \& Boratyński, which should be included in the section Atlanticae. Luzula atlantica was described by Braun-Blanquet (1928). Quézel (1958) described a new taxon from the Tibesti Mountains, and it was subordinated to L. atlantica as subspecies.

Luzula atlantica Braun-Blanq., Vierteljahrsschr. Naturf. Ges. Zürich 73: 347 (1928)

Ind. Loc.: "Im Quercetum ilicis subalpinum und auf Lichtungen zwischen 1500 und $2000 \mathrm{~m}$ im Tälchen oberhalb Zerekten"
Lectotype (here designated): Dr. R. Maire - Iter Maroccanum Undecimum / In Atlantis ditione Glaoua: in / rupestribus arenaceis quercetorum supra / Zerekten, $1500-2000 \mathrm{~m} /$ die 8 aprilis 1926 (MPU-Maire 002402).

L. spadicea sensu Litard. \& Maire in Mém. Soc. Sci. Nat. Maroc 6: 21 (1924); non DC.

L. graeca sensu Jahand. in Mém. Soc. Sci. Nat. Maroc 3(1): 111 (1923); non Kunth

Luzula atlantica was first reported by Jahandiez (1923) and published under the name of L. graeca. A year later Litardière \& Maire (1924) referred it to Luzula spadicea. Four years later it was described as a new taxon from the High Atlas Mountains by Braun Blanquet (1928). Two years later Litardière $\&$ Maire (1930) published an amplified description.

It is a diploid $2 n=12$, as reported by Galland (1988). After Galland (1988) it is close to L. alpinopilosa (Chaix) Breistr.

This taxon displays a number of morphological peculiarities that justified the creation of the section Atlanticae Kirschner within this genus (Kirschner \& Kaplan, 2001a) and the designation of L. atlantica as type of the section and its unique representative. These authors consider it to be an isolated and clearly-differentiated taxon within the genus.

It is a very localized endemic plant, found growing at middle altitudes in the High Atlas, between 1500 and $2800 \mathrm{~m}$ (Maire, 1957). Luzula atlantica is cited from the following localities of the High Atlas: au-dessus Zerekten, 1500-2000 m; Reraya, au-dessus d'Arround, 2200 m; Sidi Chamarouch, $2400 \mathrm{~m}$; Ourika, 2880m [all these localities after Jahandiez \& Maire (1931)]; Adrar Tizerag à Oukaïmeden (Fennane \& Ibn Tattou,1998); between Aït-Barka and Zerekten, Aït Barka forêt de Touzzane, Tizi'n Test northern slopes (Barbero et al., 1981); and Oukaïmeden (Dobignard \& Jordan, 1987). Emberger $\&$ Maire (1941) mentioned a doubtful record from the Anti Atlas (Jbel Kest) stating that it had no flowers or fruits. The same Anti Atlas record is mentioned as being uncertain by Fennane \& Ibn Tattou (1998).

It is an important floristic element of the NorthAfrican Balanseo-Quercion alliance (Barbero et al., 1981) and its presence in the field led to the assignation of a plant community under the name Luzulo atlanticaeQuercetum rotundifoliae (Barbero et al., 1981). Within it, typical elements can be recognized such 
as: Anarrhinum pedatum Desf., Conopodium glaberrimum (Desf.) Engstrand, Bupleurum montanum Coss. \& Durieu, Genista tournefortii Spach subsp. jahandiezii (Batt.) Talavera \& P. E. Gibbs, Luzula atlantica, Narcissus watieri Maire, Ptilostemon dyricola (Maire) Greuter and Origanum elongatum (Bonnet) Emb. \& Maire (Barbero et al., 1992).

The following herbarium material has been revised: Morocco: Grand Atlas, Reraya, au dessus de Sidi Chamarouch, au pied des grans rochers porphyriques sur la rive droite du torrent, $2380 \mathrm{~m}$, 23.07.1823, R. de Litardière s. n. (MPU-Maire); In Atlantis Majoris Valle Reraya, Sidi-Chamarouch, $2400-2500 \mathrm{~m}$, in fissuris rupium porphyr., 21.07.1924, R. Maire s. $n$. (R. Maire - Iter Maroccanum Octavum) (MPU-Maire 002401).

Luzula tibestica (Quézel) Zahran ex Romo \& Boratyński, comb. \& stat. nov.

Basionym: L. atlantica subsp. tibestica Quézel in Mém. Inst. Rech. Sahar. 4: 121 (1958)

Ind. Loc.: Emi Koussi: Lappiaz volcanique du flanc NW du cratère Kohor, où elle est localisée dans les suitements au fond de gorges obscures en compagnie de Cystopteris fragilis.

Lectotype (here designated): Mission Botanique / de l'Institut de Recherches Sahariennes / de 1'Université d'Alger / au Borkou et au Tibesti / Emi Koussi / Lappiaz du flanc NW / 3100 m / Sept.-Novembre 1956 Dr. P. Quézel (AIX 000009). Of the eight individuals that make up the sheet, the one in the upper left-hand corner has been chosen as the type.

Zahran (2010: 36) proposed this combination, but since it lacked an indication of the basionym, it is not considered to be a valid proposition.

This taxon from the Tibesti mountains can be recognised by a series of characters that separate it from $L$. atlantica. Its basal leaves can be up to $8 \mathrm{~mm}$ wide, and their length is shorter $(8-10 \mathrm{~cm})$ than in L. atlantica. Of note are its few-flowered glomerules (2-4 flowered as opposed to 2-7 flowered); its external sepals which have a longer, black arista, as opposed to reddish-brown; its capsule which is smaller $(c .1 .5 \times 1.2$ and not $2 \times 1.15) \mathrm{mm}$ and its seeds, which are also smaller $(0.6-0.7 \times c .0 .6$, and not $0.8-1 \times 0.8 \mathrm{~mm}$ ), see Table 1 .
This taxon manifests a notable geographical isolation, since it is to be found at more than $2400 \mathrm{~km}$ from the High Atlas populations. Moreover, the combined morphological characteristics, summarised in Table 1, clearly segregate both taxa. As a result of its geographic isolation and its different morphological characteristics, the specific status seems more adequate.

This plant is only known from the summit area (Emi Koussi, $3415 \mathrm{~m}$ ) of the highest range in the Tchad and Sahara (Ozenda, 1991). The peaks of the Emi Koussi mountains harbour a relictual mountain (orophile) flora (Quézel, 1957) and, in the case of the taxon under study, this is represented by a scarce number of individuals. Quézel (1957) in two weeks of detailed exploration was only able to locate a dozen plants.

Luzula tibestica has been reported from Libya (Base de données des plantes d'Afrique, version 3.3.4), but neither literature references nor herbarium material from this country have been found.

Luzula tibestica grows on culminal lappiaz in the Tibesti Mountains, between 2800 and $3400 \mathrm{~m}$, where it is found in a plant community dominated by $\mathrm{He}$ lichrysum monodianum Quézel and Dichrocephala tibestica Quézel and containing a lot of endemics such as: Nepeta tibestica Maire, Festuca tibestica Miré \& Quézel, Helictotrichon tibesticum (Miré \& Quézel) Holub, Agrostis tibestica Miré \& Quézel, Spergularia tibestica Quézel \& Monnier and Bromus tibesticus Maire (Quézel, 1965). In this plant community, Luzula tibestica and Campanula filicaulis Durieu var. tibestica Quézel are assumed to be representants of the Atlas Mountain lineages (Quézel, 1965), which represent a minority when compared to the oroafrican lineage, clearly more dominant.

The following herbarium material has been revised: Tchad: Mission Botanique de l'Institut de Recherches Sahariennes de l'Université d'Alger, au Borkou et au Tibesti, Emi Koussi, Lappiaz du flanc NW, 3100 m, Sept.-Novembre 1956, P. Quézel s. n. (AIX 000009); Mission Botanique de l'Institut de Recherches Sahariennes de l'Université d'Alger, au Borkou et au Tibesti, Sugzugan, 3100 m, Sept.Novembre 1958, P. Quézel s. n. (AIX 000010).

\section{Biogeographical insights}

The close relationship between Atlas and Tibesti taxa was considered to be evidence of a continuous flora present in the mountains of North (Atlas Tibes- 
Table 1. Comparison of morphological characters for the two taxa.

\begin{tabular}{|lccccc|}
\hline Taxon & Leaf length $(\mathbf{c m})$ & Leaf width $(\mathbf{m m})$ & Arista of sepals & Capsule $(\mathbf{m m})$ & Seeds $(\mathbf{m m})$ \\
\hline L. atlantica & $10-13$ & $8-9.5$ & reddish-brown & $2 \times 1.15$ & $0.8-1 \times 0.8$ \\
L. tibestica & $8-10$ & $7.1-7.9$ & black & $1.5 \times 1.2$ & $0.6-0.7 \times 0.6$ \\
\hline
\end{tabular}

ti) and Central Africa (Axelrod, 1975; Quézel, 1978; Sunding, 1979). Many elements of this hypothetical continuous flora disappeared from several areas of North Africa after major climatic changes during the late Tertiary and the Quaternary (Axelrod, 1975; Quézel, 1978).

The isolated Saharan mountains (Hoggar, Aïr and Tibesti) have given rise to relictual populations of plants originating from the northwest, south and southeast (Lehouérou, 1997). This high degree of isolation, as in the case of Tibesti, has favoured the speciation process. These events probably go back to arid periods towards the end of the Miocene (Griffin, 2002) and more concretely to the Messinian Salinity Crisis (Krijgsman et al., 1999). At present the Tibesti is a refuge for mountain-specific flora (Anthelme et al., 2008).

Paleological data have provided more detailed accounts of paleoclimate, paleogeography (Schuster et al., 2006) and vegetational changes in northern Africa (Menocal, 2004; Kröpelin et al., 2008; Watrin et al., 2009) from the late Miocene to our days.

The existence of a Trans-saharan route via Hoggar and Tibesti to Jebel Marra and the Ethiopian highlands for the migration of plants has been pointed out by Wickens (1976) and Quézel (1958; 2002). This route seems to be the pathway employed by the taxa of the rand flora, and it highlights the radiation process of some genera, such as Olea L., Myrtus L. and Asparagus L., in order to explain the vicariance process in plants.

This previous hypothesis has been ratified by Quézel \& Martínez (1958). They have satisfactory demonstrated the extension of the Mediterranean flora into the Sahara during the Pleistocene, which would explain the survival of taxa with strong Mediterranean affinities in the higher elevations of the Saharan mountains. After Zarhan (2010), some of the characteristic species of this arid mountain vegetation in the Tibesti region are: Agrostis tibestica, Festuca tibestica, Helictotrichon tibesticum and Lu- zula tibestica, among others. Some such species for the Jebel Marra: Silene lynesii Norman, Phagnalon scalarum Schweinf. ex Blatt. subsp. scalarum and Phagnalon scalarum subp. meridionales Quézel, after Wickens (1976).

The Saharan mountains host vegetation with a high level of endemism (Quézel, 1965). Many of them, as opposed to taxa from the lowlands with a paleotropical affinity, have a clear oromediterranean or high mountain Mediterranean character and are remnants of a relictic flora.

Examining patterns of geographic distribution, endemism and morphology, this section of the genus Luzula is relict in origin, and derived from mountain relatives present during the Tertiary, since a mountain flora was present from the Atlas to the Tibesti Mountains in the late Miocene (Axelrod, 1975; Quézel, 1978; Sunding, 1979).

The genus Luzula originated about 55 Mya ago (Bremer, 2002). Luzula atlantica emerged as a terminal taxon related to the section Alpinae derived from a total of seven missing haplotypes. These results may confirm their placement into a separate taxonomic group (Drábková \& Vlcek, 2010). This being the case, it is assumed that the extant taxa are relicts of the larger distribution tertiary flora that became partly fragmented or even extinct following the aridification episodes that took place from the end of the Miocene onwards. This, together with the low dispersal capacity of the taxa of this section, would support the hypothesis of and adaptative diversification in situ from a common ancestor (from among the mountain ranges near Tibesti and the Atlas chain), which would have colonized the Tibesti massif in the wake of the intense volcanic activity in the Tibesti Volcanic Province at the end of the Pliocene (Permenter \& Oppenheimer, 2007). This ancestor would probably be close to the present Luzula atlantica of the Atlas, a mountains region in which it would have evolved after the last glacial episodes (Hughes et al., 2006). This ancestor would 
have not persisted in the other massifs situated between the Atlas and the Ethiopian highlands: Hoggar, Aïn, Jbel Marra, Mount Mubo, and if in one of these it had established itself, at a posterior date it would have become extinct.

\section{ACKNOWLEDGMENTS}

To Joel Mathez, Peter Schäfer and Véronique Bourgade from the Herbarium MPU for the facilities to consult the material of Luzula atlantica, and to Muriel Durand from the Museum d'Histoire Naturelle d'Aix en Provence for providing the facilities to enable the consulting of the L. tibestica materials. This paper has been financed by "Ajuts a grups de recerca consolidats, 2009SGR0439, de la Generalitat de Catalunya" and "Proyectos Intramurales de Incorporación del CSIC: 2009930I161".

\section{REFERENCES}

Anthelme, F., Waziri Mato, M. \& Maley, J. 2008. Elevation and local refuges ensure persistence of mountain specific vegetation in the Nigerian Sahara. J. Arid Environm. 72: 2232-2242.

Axelrod, D. I. 1975. Evolution and biogeography of MadreoThetyan sclerophyl vegetation. Ann. Missouri Bot. Gard. 62: 280-334.

Barbero, M. R., Loisel, R. \& Quézel, P. 1992. Biogeography, ecology and history of Mediterranean Quercus ilex ecosystems. Plant Ecology 90-100: 19-34.

Barbero, M., Quézel, P. \& Rivas-Martínez, S. 1981. Contribution à l'étude des groupements forestiers et préforestiers du Maroc. Phytocoenologia 9(3): 311-412.

Base de données des plantes d'Afrique (version 3.3.4). Conservatoire et Jardin botaniques de la Ville de Genève and South African National Biodiversity Institute, Pretoria. Consulted on February, 2011, in http://www.ville-ge.ch/ musinfo/bd/cjb/africa/

Braun-Blanquet, J. 1928. Zur Kenntnis der Vegetationsverhältnisse des Grossen Atlas. Beiblatt Nr 15, Vierteljahrsschr. Naturf. Ges. Zürich 73: 334-357.

Bremer, K. 2002. Gondwanan evolution of the grass alliance of families (Poales). Evolution 56: 1374-1387.

Dobignard, A. \& Jordan, D. 1987. Nouvelles observations sur la flore du Maroc, 1. Contributions à l'étude de la flore du Haut Atlas. Saussurea 18: 64-104.

Drábková, L. Z. \& Vlcek, C. 2010. Molecular phylogeny of the genus Luzula DC. (Juncaceae, Monocotyledones) based on plastome and nuclear ribosomal regions: A case of incongruence, incomplete lineage and hybridisation. Molec. Phylogen. Evol. 57: 536-551.

Emberger, L. \& Maire, R. 1941. Catalogue des plantes du Maroc 4. Imprimerie Minerva, Alger.

Fennane, M. \& Ibn Tattou, M. 1998. Catalogue des plantes rares, menacées ou endémiques du Maroc. Bocconea 8: 5-244.

Galland, N. 1988. Recherche sur l'origine de la flore orophile du Maroc. Travaux Inst. Scient., série botanique 35: 1-168.

Griffin, D. L. 2002. Aridity and humidity: two aspects of the late Miocene climate of North Africa and the Mediterranean. Palaeogeogr. Palaeoclimatol. Palaeoecol. 182 (1): 65-91.

Hughes, P. D., Woodward, J. C. \& Gibbard, P. L. 2006. Quaternary glacial history of the Mediterranean mountains. Progr. Phys. Geography 30: 334-364.

Jahandiez, E. 1923. Contribution à l'étude de la Flore du Maroc. Mém. Soc. Sci. Nat. Maroc 3(1): 102-120.

Jahandiez, E. \& Maire, R. 1931. Catalogue des plantes $d u$ Maroc 1. Imprimerie Minerva, Alger.

Kirschner, J. H., Baslev, H., Ceska, A. et al. 2002. Juncaceae 1: Rostkovia-Luzula, Species Plantarum: Flora of the World Part 6: 1-237. Australian Biological Resources, Canberra.

Kirschner, J. \& Kaplan, Z. 2001a. Taxonomic and nomenclatural notes on Luzula and Juncus (Juncaceae). Taxon 50: 1107-1113.

Kirschner, J. \& Kaplan, Z. 2001b. Taxonomic monographs in relation to global Red Lists. Taxon 51: 155-158.

Klopper, R. R., Chatelain, C., Bänninger, V. et al. 2006. Checklist of the flowering Plants of Sub-Saharan Africa. An index of accepted names and synonyms. Southern African Botanical Diversity Network Report 42. Sabonet, Pretoria.

Krijgsman W., Hilgen F. J., Raffi I., Sierro F. J. \& Wilson D. S. 1999. Chronology, causes and progression of the Messinian Salinity Crisis. Nature 400: 652-655.

Kröpelin, S., Verschuren, D., Lézine, A. M. et al. 2008. ClimateDriven Ecosystem Succession in the Sahara: The Past 6000 years. Science 320: 765-768.

Lehouérou, H. N. 1997. Climate, flora and fauna changes in the Sahara over the past 500 million years. J. Arid Environm. 37: 319-347.

Litardière, R. \& Maire, R. 1924. Contribution à l'étude de la Flore du Grand Atlas. Mém. Soc. Sci. Nat. Maroc 4(1): 1-32.

Litardière, R. \& Maire, R. 1930. Contribution à l'étude de la Flore du Maroc. Mém. Soc. Sci. Nat. Maroc 26(2): 1-68.

Maire, R. 1957. Flore de l'Afrique du Nord 4. Paul Chevalier, Paris.

Menocal, P. B. de 2004. African climate change and the faunal evolution during the Pliocene-Pleistocene. Earth Planet. Sci. Lett. 220: 3-24.

Ozenda, P. 1991. Flore du Sahara. 2ème édition, Éditions du Centre National de la Recherche Scientifique, Paris.

Permenter, J. L. \& Oppenheimer, C. 2007. Volcanoes on the Tibesti massif. Bull. Vulcanol. 69: 609-626.

Quézel, P. 1957. Présence d'une flore orophile résiduelle sur les sommets de l'Émi Koussi (Massif de Tibesti, Sahara). Compt. Rend. Acad. Sci. (Paris) 254: 1656-1657.

Quézel, P. 1958. Mission botanique au Tibesti. Mém. Inst. Rech. Sahar. 4: 1-357.

Quézel, P. 1965. La végétation du Sahara. Gustav Fisher Verlag. Stuttgart.

Quézel, P. 1978. Analysis of the Flora of the Mediterranean and Saharan Africa. Ann. Missouri Bot. Gard. 65: 479-534.

Quézel, P. 1981. Les hautes montagnes du Maghreb et du Proche-Orient: essai de mise en parallèle des caractères phytogéographiques. Anales Jard. Bot. Madrid 37: 353-372.

Quézel, P. 2002. Réflexions sur l'évolution de la flore et la végétation au Maghreb méditerranéen. Ibis Press, 2éme édition, Paris.

Quézel, P. \& Martinez, C. 1958. Étude palynologique de deux diatomites du Borkou. Bull. Soc. Hist. Nat. Afr. N. 49: 230-244.

Quézel, P. \& Médail, F. 2003. Écologie et biogéographie des 
forêts du Bassin Méditerranéen. Elsevier, Paris.

Sunding, P. 1979. Origins of the Macaronesian flora. In: Bramwell, D. (Ed.), Plants and Islands. Academic Press, New York: 13-40.

Schuster, M., Duringer, P., Ghienne, J. F., Vigneaud, P., Mackaye, H. T., Likius, A. \& Brunet, M. 2006. The age of the Sahara Desert. Science 311: 821.

Watrin, J., Lézine, A. M. \& Hély, C. 2009. Plant Migration and plant communities at the time of the "green Sahara". Comp. Rend. Geosci. 341: 656-670.

Wickens, G. E. 1976. The flora of Jebel Marra (Sudan Republic) and its geographical affinities. Kew Bulletin additional series 5: 1-368. Royal Botanic Gardens, Kew.

Zahran, M. A. 2010. Climate-Vegetation: Afro-Asian Mediterranean and Red Sea Coastal Lands. Plant and vegetation 4. Springer Verlag, Berlin. 